\title{
ANALISIS KESENJANGAN PERENCANAAN DAN PELAKSANAAN PEMBELAJARAN KURIKULUM 2013 DI SD NEGERI 4 KALIUNTU
}

\author{
Kadek Dewi Suryantari, Made Sumantri \\ Jurusan Pendidikan Guru Sekolah Dasar, Fakultas Ilmu Pendidikan \\ Universitas Pendidikan Ganesha, Jln. Udayana No. 11 Singaraja \\ e-mail: kadekdewi_suryantari@yahoo.com
}

\begin{abstract}
This research aimed to determine how large the discrepancy between the ideal condition and the implementation of 2013 curriculum in teaching and learning process at SD Negeri 4 Kaliuntu reviewed from the lesson plan and teaching learning process. This research was evaluative research which apply discrepancy model. Measurement of the program effectiveness was done by comparing the ideal conditions, based on Permendikbud No. 103 of 2014, with the real conditions on the implementation of 2013 Curriculum at SD Negeri 4 Kaliuntu. Lesson plan data, was measured by the study documentation methode. Meanwhile, the teaching and learning process data was measured by observation methode. Subject of this research consisted of 6 teachers of SD Negeri 4 Kaliuntu. The data scores was form for all variables were analyzed by using the Wilcoxon's signed rank test. The sign difference and score difference were calculated with a predetermined standard. The result of the analysis indicate that the large of discrepancy between ideal conditions (based on Permendikbud No. 103 of 2014) and the implementation of 2013 Curriculum at SD Negeri 4 Kaliuntu in terms of lesson plan is $12,17 \%$. The discrepancy lies on indicators of learning activities, assessment of learning result, media and learning resources. Reviewed from the teaching learning process, the discrepancy occurs at $19.17 \%$. The discrepancy occurs in the indicator of giving apperception, convey of evaluation techniques that will be used by teachers, students are directed reflection of the activities that have been implemented, and the provision of follow-up by giving remedial, enrichment, or giving assignments.
\end{abstract}

Keywords: discrepancy, lesson plan, teaching and learning process, Permendikbud No. 103/ 2014

\begin{abstract}
ABSTRAK: Penelitian ini bertujuan untuk mengetahui besarnya kesenjangan antara implementasi Kurikulum 2013 di SD Negeri 4 Kaliuntu dan Permendikbud Nomor 103 Tahun 2014 ditinjau dari perencanaan dan pelaksanaan pembelajaran. Penelitían ini termasuk penelitían evaluatif model diskrepansi (discrepancy model). Pengukuran efektivitas program dilakukan dengan membandingkan antara kondisi ideal (standar) dan kondisi riil tentang implementasi Kurikulum 2013 di SD Negeri 4 Kaliuntu berdasarkan Permendikbud Nomor 103 Tahun 2014. Data perencanaan pembelajaran dikumpulkan dengan metode studi dokumentasi, sedangkan data pelaksanaan pembelajaran dikumpulkan dengan metode observasi. Subjek penelitian berjumlah 6 orang guru di SD Negeri 4 Kaliuntu. Data berupa skor semua objek penelitian dianalisis dengan menggunakan prosedur uji tanda berjenjang Wilcoxon, kemudian dihitung tanda beda dan besar beda dengan standar yang telah ditentukan. Hasil analisis menunjukkan bahwa besarnya kesenjangan implementasi Kurikulum 2013 di SD Negeri 4 Kaliuntu berdasarkan Permendikbud Nomor 103 Tahun 2014 ditinjau dari perencanaan pembelajaran adalah sebesar 12,17\%. Kesenjangan tersebut terletak pada indikator kegiatan pembelajaran, penilaian hasil belajar, media dan sumber belajar. Ditinjau dari pelaksanaan pembelajaran, kesenjangan terjadi sebesar 19,17\%. Kesenjangan tersebut terdapat pada indikator pemberian apersepsi, penyampaian teknik penilaian yang akan digunakan guru, peserta didik diarahkan refleksi terhadap kegiatan yang sudah dilaksanakan, dan pemberian tindak lanjut dalam bentuk remidi, pengayaan, dan atau pemberian tugas.
\end{abstract}

Kata-kata kunci: kesenjangan, perencanaan pembelajaran, pelaksanaan pembelajaran, Permendikbud No.103/2014 
Pendidikan memiliki peranan yang sangat penting dalam membentuk manusia seutuhnya yang dapat menentukan kualitas suatu bangsa. Keberhasilan suatu pendidikan, tentunya didukung oleh komponen-komponen yang saling berkaitan, seperti kurikulum, tenaga pendidik, peserta didik, serta sarana dan prasarana lainnya. Kurikulum merupakan salah satu komponen penting dalam penyelenggaraan pendidikan. Proses pendidikan dalam kegiatan pembelajaran atau dalam kelas, akan bisa berjalan dengan lancar, kondusif, interaktif, dan lain sebagainya apabila pendidikan bisa dijalankan dengan baik ketika kurikulum menjadi penyangga utama dalam proses belajar mengajar (Kamil, 2014). Kurikulum dapat dikatakan sebagai jantungnya pendidikan, sebab baik dan buruknya hasil pendidikan ditentukan oleh kurikulum. Karena peranan kurikulum sangat penting, maka setiap kurun waktu tertentu kurikulum dievaluasi kemudian disesuaikan dengan perkembangan zaman.

Sepanjang perkembangan sejarah pendidikan di Indonesia, pemerintah sudah beberapa kali mengadakan usaha-usaha pembaharuan kurikulum (Pertiwi, 2015). Tahun 1994 disebut Kurikulum 1994. Akan tetapi, karena tuntutan kemajuan zaman dalam hal ini adalah keadaan dan kebutuhan peserta didik pada masa sekarang dan yang akan datang, yang sangat berbeda dengan sebelumnya, maka kurikulum pendidikan tahun 1994 telah digantikan dengan kurikulum berbasis kompetensi (KBK) yang diluncurkan ke masyarakat pada tahun 2004. Setelah KBK diberlakukan, kemudian diperbaharui lagi dengan kurikulum baru pada tahun 2006, yang disebut Kurikulum Tingkat Satuan Pendidikan (KTSP). Tetapi karena tuntutan kemajuan zaman yang semakin berkembang pesat, ditahun ajaran 2013/2014 kurikulum KTSP kembali disempurnakan lagi menjadi kurikulum baru yaitu Kurikulum 2013.

Kurikulum 2013 merupakan langkah lanjutan pengembangan Kurikulum Berbasis Kompetensi yang telah dirintis pada tahun 2004 dan KTSP yang dirintis pada tahun 2006 yang mencakup kompetensi sikap, pengetahuan dan keterampilan secara terpadu. Proses pembelajaran dirancang berpusat pada peserta didik (student centered active leaming), tidak lagi berpusat pada guru (teacher centered learning). Selain itu, sifat pembelajaran kontekstual yang artinya guru tidak banyak beracuan pada buku teks saja tetapi juga harus mampu mengaitkan materi yang disampaikannya secara kontekstual. Pelaksanaan pembelajaran pada kurikulum 2013 mengamanatkan pendekatan scientific atau ilmiah dalam pelaksanaannya (Kurinasih dan Sani, 2014). Rancangan kurikulum 2013 bersifat sentralistik, yang mana pemerintah pusat dan daerah memiliki kendali kualitas dalam pelaksanaan kurikulum di tingkat satuan pendidikan. Pemerintah menyiapkan semua komponen kurikulum sampai buku teks dan pedoman. Termasuk penyusunan silabus.

Sejalan dengan diberlakukannya Kurikulum 2013, agar penyelenggaraan pendidikan di wilayah Negara Kesatuan Republik Indonesia dapat memenuhi acuan atau standar tertentu, pemerintah dalam hal ini Menteri Pendidikan dan Kebudayaan telah menerbitkan berbagai peraturan yang disebut dengan Peraturan Menteri Pendidikan dan Kebudayaan (Permendikbud). Permendikbud yang baru saja diterbitkan oleh pemerintah yang menjelaskan bagaimana pelaksanaan kurikulum 2013 yang menyangkut perencanaan pembelajaran dan pelaksanaan pembelajaran adalah Permendikbud Nomor 103 tahun 2014 tentang Pembelajaran pada Pendidikan Dasar dan Pendidikan Menengah. Secara umum sesuai dengan Permendikbud Nomor 103 Tahun 2014, guru dituntut untuk menyusun suatu rencana pelaksanaan pembelajaran (RPP) yang nantinya akan diterapkan pada proses pembelajaran. RPP menjadi pedoman guru selama melaksanakan pembelajaran agar proses pembelajaran yang dilaksanakan lebih terarah dan tidak melenceng dari tujuan yang ingin dicapai. Selain itu, dalam Permendikbud No.103 Tahun 2014, guru juga dituntut untuk melaksanakan proses pembelajaran secara interaktif, inspiratif, menantang, menyenangkan, memotivasi peserta didik untuk berpartisipasi aktif, serta memberikan ruang yang cukup bagi prakarsa, kreativitas, dan kemandirian sesuai dengan bakat, minat, dan perkembangan fisik serta psikologis peserta didik. 
Berdasarkan hasil wawancara yang dilakukan dengan Kepala SD N 4 Kaliuntu, diketahui bahwa terdapat beberapa kendala yang dirasakan oleh guru setelah penerapan kurikulum 2013 sekarang ini, yaitu membutuhkan waktu adaptasi yang cukup lama bagi para pendidik, khususnya guru kelas 3 dan guru kelas 6, karena pembelajaran dalam kurikulum 2013 tidak lagi dalam bentuk mata pelajaran, melainkan berdasarkan tema sebagai pemersatu. Guru kelas 3 dan kelas 6 juga kurang mampu menguasai kelas dengan baik. Beberapa pendidik juga sedikit kesulitan dalam menyusun RPP yang baik dan benar sesuai dengan tuntutan Permendikbud Nomor 103 tahun 2014 tentang kurikulum 2013, karena harus mengintegrasikan berbagai mata pelajaran ke dalam satu pembelajaran serta banyaknya penilaian yang harus dicantumkan. Kendala juga terjadi dalam pemilihan media pembelajaran yang sesuai dengan tema yang akan dibahas.

Untuk mengetahui efektivitas implementasi kurikulum 2013 berdasarkan Permendikbud No.103 tahun 2014 di SD N 4 Kaliuntu, maka dilakukan penelitian tentang implementasi kurikulum 2013 yang difokuskan pada penyusunan RPP dan pelaksanaan pembelajaran yang dilaksanakan oleh guru. Penelitian yang dilakukan berupa evaluasi program. Arikunto (2008:18) mendefinisikan, "Evaluasi program adalah upaya untuk mengetahui tingkat keterlaksanaan suatu kebijakan secara cermat dengan cara mengetahui efektivitas masing-masing komponennya". Evaluasi program bertujuan untuk mengetahui pencapaian tujuan program dengan langkah mengetahui keterlaksanaan kegiatan program. Untuk mengetahui kesenjangan implementasi Kurikulum 2013 di SD Negeri 4 Kaliuntu berdasarkan Permendikbud No.103 Tahun 2014, maka dilaksanakan penelitian yang berjudul "Analisis Kesenjangan Perencanaan dan Pelaksanaan Pembelajaran Kurikulum 2013 Berdasarkan Permendikbud No.103 Tahun 2014 di SD Negeri 4 Kaliuntu, Kecamatan Buleleng, Kabupaten Buleleng Tahun Ajaran 2015/2016".

Tujuan Penelitian ini adalah (1) untuk menganalisis perbedaan antara Rencana Pelaksanaan Pembelajaran (RPP) Kurikulum 2013 yang dibuat oleh guru SD N 4 Kaliuntu Tahun Pelajaran 2015/2016 dengan standar proses Permendikbud No.103 Tahun 2014, (2) untuk menganalisis perbedaan antara proses pembelajaran Kurikulum 2013 yang dilakukan oleh guru SD N 4 Kaliuntu Tahun Pelajaran 2015/2016 dengan standar proses Permendikbud No.103 Tahun 2014.

\section{METODE}

Penelitian ini merupakan penelitian evaluatif yang dilaksanakan di SD Negeri 4 Kaliuntu. Hadi dan Mutrofin (2005:1) menyatakan, "Riset evaluasi dimaksudkan untuk mengukur hasil suatu kebijakan, program, proyek produk atau aktivitas tertentu". Secara metodelogis, penelitian ini termasuk penelitian evaluatif karena berorientasi pada analisis berdasarkan pendekatan evaluasi program yang menganalisis kesenjangan program dengan variabel-variabel dalam acuan dengan model kesenjangan yang dikonfirmasikan dengan target sasaran yang merupakan acuan (standar) suatu program. Jumlah subjek penelitian ini adalah 6 orang yang terdiri dari guru kelas I, II, III, IV, V dan VI di SD Negeri 4 Kaliuntu. Selain guru di SD Negeri 4 Kaliuntu, subjek lain dalam penelitian ini adalah Permendikbud Nomor 103 Tahun 2014. Objek dalam penelitian ini adalah rencana pelaksanaan pembelajaran yang disusun oleh guru SD Negeri 4 Kaliuntu dan pelaksanaan pembelajaran yang dilakukan oleh SD Negeri 4 Kaliuntu. Penelitian ini dirancang dengan menggunakan Model Kesenjangan (Dicrepancy Model) yang dikembangkan oleh Malcom Provus. Model Kesenjangan (Dicrepancy Model) merupakan model evaluasi yang menekankan pada pandangan adanya kesenjangan di dalam pelaksanaan program (Arikunto, 2008:48). Model ini digunakan oleh evaluator untuk mengukur besarnya kesenjangan yang ada di setiap komponen program.

Data yang dikumpulkan dalam penelitian ini terdiri atas perencanaan pembelajaran dan pelaksanaan pembelajaran. Metode yang digunakan untuk mengumpulkan data perencanaan pembelajaran adalah metode studi dokumentasi dengan menggunakan instrumen lembar studi dokumentasi. Metode yang digunakan untuk mengumpulkan data pelaksanaan pembelajaran adalah metode observasi dengan instrumen lembar observasi. 
Penyusunan instrumen pengumpulan data berpedoman pada kisi-kisi yang telah disusun berdasarkan Permendikbud No.103 Tahun 2014. Sebelum digunakan, item-item instrumen terlebih dahulu dilakukan uji validitas isi. Validitas isi adalah kecocokan di antara isi alat ukur dengan isi sasaran ukur (Aimeay, 2012). Penilaian ini dilakukan untuk mengetahui seberapa jauh instrumen telah mencerminkan segala aspek yang hendak diukur. Proses validasi instrument dilakukan oleh dua orang expert judgement. Perhitungan validitas isi dilakukan menggunakan formula Gregory. Berdasarkan hasil perhitungan diperoleh bahwa seluruh instrumen penelitian dinyatakan valid dan dapat digunakan untuk mengumpulkan data penelitian.

Data hasil penelitian kemudian dianalisis. Penelitian ini menggunakan uji non parametrik dengan mengikuti prosedur uji jenjang bertanda wilcoxon. Suciptawati (2009), menyatakan bahwa uji wilcoxon adalah uji non parametrik untuk menguji signifikansi hipotesis komparatif 2 sampel berpasangan. Uji jenjang bertanda wilcoxon bertujuan untuk mengetahui apakah terdapat perbedaan nyata (kesenjangan) antara standar acuan pelaksanaan permendikbud Nomor 103 Tahun 2014 dengan pelaksanaan sesungguhnya yang dilakukan oleh pendidik di SD Negeri 4 Kaliuntu. Langkah-langkah analisis data dengan menggunakan uji bertanda wilcoxon adalah sebagai berikut. 1) Tabulasi skor dari setiap variabel; 2) Menghitung ratarata skor setiap variabel (Y); 3) Membandingkan rata-rata skor yang diperoleh (Y) dengan besarnya acuan yang ditetapkan(X); 4) Menghitung arah (tanda beda) dan besarnya beda acuan (X) dengan rata-rata perolehan skor $(\mathrm{Y}),(\mathrm{X}-\mathrm{Y}) ; 5)$ Menghitung persentase beda acuan (X) dengan rata-rata perolehan skor $(\mathrm{Y}),(\mathrm{X}-\mathrm{Y}) \% ; 6)$ Mengkonfirmasi tanda beda (+ ; -) dan besarnya beda ke dalam kategori ; 7) Jika arah beda bertanda positif $(+)$, berarti tidak terdapat kesenjangan antara standar acuan dengan pelaksanaan; 8) Jika arah beda negatif (-), berarti terdapat kesenjangan antara standar acuan dengan pelaksanaan ; 9) Menghitung persentase besarnya beda negatif $(-) ; 10)$ Mengkategorikan tingkat kesenjangan dengan kriteria yang telah ditetapkan. Kriteria acuan diskrepansi (kesenjangan) adalah sebagai berikut.

11) Hasil analisis komponen yang diteliti dimaknai sehingga diperoleh gambaran perencanaan pelaksanaan pembelajaran dan pelaksanaan pembelajaran dengan kurikulum 2013 berdasarkan Permendikbud No.103 Tahun 2014 di SD Negeri 4 Kaliuntu. 12) Penelusuran, pengkonfirmasian, dan penyimpulan terhadap pelaksanaan pembelajaran berdasarkan Permendikbud No 103 Tahun 2014 yang dilihat dari rencana pelaksanaan pembelajaran dan proses pembelajaran yang dilaksanakan oleh guru SD Negeri 4 Kaliuntu.

Tabel 1. Kriteria Acuan Diskrepansi (Kesenjangan)

\begin{tabular}{|c|c|}
\hline $\begin{array}{l}\text { Besar Beda dengan Acuan } \\
\text { (Standar) } \%\end{array}$ & Kategori Kesenjangan \\
\hline $\mathrm{D}=0 \%$ & Tanpa Kesenjangan \\
\hline $0 \%<\mathrm{D} \leq 20 \%$ & Sangat Kecil \\
\hline $20 \%<\mathrm{D} \leq 40 \%$ & Kecil \\
\hline $40 \%<\mathrm{D} \leq 60 \%$ & Cukup Besar \\
\hline $60 \%<\mathrm{D} \leq 80 \%$ & Besar \\
\hline $80 \%<\mathrm{D} \leq 100 \%$ & Sangat Besar \\
\hline
\end{tabular}

(Sumber: Dantes dalam Sudarma, 2011) 


\section{HASIL DAN PEMBAHASAN}

\section{Hasil}

Data yang telah dikumpulkan terlebih dahulu dianalisis komponen, subkomponen dan indikator dari data perencanaan dan pelaksanaan pembelajaran berdasarkan Permendikbud No.103 Tahun 2014. Hal tersebut dilakukan untuk mengetahui seberapa besar kesenjangan pembelajaran dengan kurikulum 2013 berdasarkan Permendikbud No.103 Tahun 2014 di SD Negeri 4 Kaliuntu.

Hasil analisis kesenjangan pada masingmasing indikator RPP dapat dilihat pada Tabel 2. Berdasakan tabel 2 di atas, diketahui bahwa terdapat 6 indikator yang tidak mengalami kesenjangan dan 14 indikator yang mengalami kesenjangan antara standar acuan dengan perencanaan pembelajaran yang di susun oleh guru. Indikator yang tidak mengalami kesenjangan adalah indikator 1 (mencantumkan nama satuan pendidikan), indikator 2 (mencantumkan tema dan subtema), indikator 3 (mencantumkan kelas dan semester), indikator 5 (mencantumkan kompetensi inti secara utuh dari KI-1 sampai KI-4), indikator 6 (mencantumkan Kompetensi Dasar), dan indikator 12 (kegiatan pembelajaran terdiri atas kegiatan pendahuluan, inti, dan penutup).

Indikator perencanaan pembelajaran yang mengalami kesenjangan dengan kategori sangat kecil adalah indikator 4 (alokasi waktu sesuai dengan keperluan untuk tercapainya kompetensi dasar dan beban belajar) besar kesenjangan $6,6 \%$, indikator 7 (kompetensi dasar harus memuat secara utuh kompetensi dasar sikap spiritual (KD dari KI-1), sosial (KD dari KI-2), pengetahuan (KD dari KI-3), dan ketrampilan (KD dari KI-4)) besar kesenjangan $3,4, \%$ indikator $\quad 8$ (mencantumkan indikator pencapaian kompetensi dan dirumuskan berdasarkan kompetensi dasar) besar kesenjangan 10\%, indikator 9 (materi pembelajaran memuat fakta, konsep, prinsip, dan prosedur vang relevan) besar kesenjangan 3,4\%, indikator 10( materi pembelajaran ditulis dalam bentuk butir-butir sesuai dengan rumusan indikator pencapaian kompetensi) besar kesenjangan $20 \%$, indikator 11 (kegiatan pembelajaran sesuai dengan pendekatan pembelajaran saintifik dan menggunakan model pembelajaran inovatif) besar kesenjangan $3,4 \%$, indikator 13 (memfasilitasi peserta didik untuk belajar secara mandiri) besar kesenjangan $13,4 \%$, indikator 14 (kegiatan pembelajaran yang dirancang menjadikan lingkungan sekitarnya sebagai sumber belajar) besar kesenjangan 20\%, indikator 16 (dalam masing-masing kegiatan pembelajaran dicantumkan alokasi waktu yang sudah direncanakan) besar kesenjangan 10\%, dan indikator 17 (mencantumkan teknik penilaian, instrument penilaian dan pembelajaran remedial dan pengayaan) besar kesenjangan $16,6 \%$.

Selanjutnya, komponen perencanaan pembelajaran yang mengalami kesenjangan dengan kategori kecil $(\mathrm{K})$ terletak pada nomor butir 15 yaitu pada indikator memuat rancangan program pemberian umpan balik positif dan penguatan. Pada indikator ini, terdapat kesenjangan sebesar 23,4\%. Kemudian, kesenjangan dengan kategori kecil (K) juga terlihat pada nomor butir 17, yaitu pada indikator mencantumkan teknik penilaian, instrumen penilaian dan pembelajaran remedial dan pengayaan dengan kesenjangan sebesar 26,6\%. Kesenjangan dengan kategori kecil (K) nampak pula pada nomor butir 19, yakni pada indikator mempertimbangkan penerapan teknologi informasi dan komunikasi secara terintegrasi, sistematis, dan efektif sesuai dengan situasi dan kondisi dengan kesenjangan mencapai $40 \%$. Dan yang terakhir, kesenjangan dengan kategori kecil (K) terdapat pada nomor butir 20 yaitu pada indikator mencantumkan sumber belajar yang dapat berupa buku, media cetak dan elektronik, alam sekitar dan sumber belajar lain yang relevan dengan kesenjangan sebesar $30 \%$. 
Tabel 2. Analisis Kesenjangan pada Indikator Perencanaan Pembelajaran yang Disusun Oleh Guru Di SD Negeri 4 Kaliuntu

\begin{tabular}{|c|c|c|c|c|c|c|}
\hline \multicolumn{7}{|c|}{ Perencanaan Pembelajaran } \\
\hline No. Butir & Standar & Skor & $\begin{array}{l}\text { Tanda } \\
\text { Beda }\end{array}$ & Besar Beda & Persentase Besar Beda (\%) & Kategori \\
\hline 1 & 100 & 100 & - & 0 & 0 & TK \\
\hline 2 & 100 & 100 & - & 0 & 0 & TK \\
\hline 3 & 100 & 100 & - & 0 & 0 & TK \\
\hline 4 & 100 & 93,4 & - & $-6,6$ & 6,6 & SK \\
\hline 5 & 100 & 100 & - & 0 & 0 & TK \\
\hline 6 & 100 & 100 & - & 0 & 0 & TK \\
\hline 7 & 100 & 96,6 & - & $-3,4$ & 3,4 & SK \\
\hline 8 & 100 & 90 & - & -10 & 10 & SK \\
\hline 9 & 100 & 80 & - & -20 & 20 & SK \\
\hline 10 & 100 & 80 & - & -20 & 20 & SK \\
\hline 11 & 100 & 96,6 & - & $-3,4$ & 3,4 & SK \\
\hline 12 & 100 & 100 & - & 0 & 0 & TK \\
\hline 13 & 100 & 86,6 & - & $-13,4$ & 13,4 & SK \\
\hline 14 & 100 & 80 & - & -20 & 20 & SK \\
\hline 15 & 100 & 76,6 & - & $-23,4$ & 23,4 & K \\
\hline 16 & 100 & 90 & - & -10 & 10 & SK \\
\hline 17 & 100 & 73,4 & - & $-26,6$ & 26,6 & K \\
\hline 18 & 100 & 83,4 & - & $-16,6$ & 16,6 & SK \\
\hline 19 & 100 & 60 & - & -40 & 40 & $\mathrm{~K}$ \\
\hline 20 & 100 & 70 & - & -39 & 30 & K \\
\hline Jumlah & 2000 & 1756,6 & - & $-243,6$ & 243,6 & \\
\hline Rata-rata & 100 & 87,83 & - & $-12,17$ & 12,17 & SK \\
\hline
\end{tabular}

Dari sajian data pada Tabel 2, komponen perencanaan pembelajaran yang memiliki tingkat kesenjangan yang paling besar adalah indikator nomor butir 19 yaitu tentang penerapan teknologi informasi dan komunikasi secara terintegrasi, sistematis dan efektif sesuai dengan situasi dan kondisi dengan kesenjangan sebesar $40 \%$.

Rata-rata kesenjangan pada indikator perencanaan pembelajaran adalah $12,17 \%$. Kesenjangan tersebut tergolong dalam kategori sangat kecil (SK)

Pada indikator yang tidak mengalami kesenjangan menunjukkan bahwa kondisi riil sudah sesuai dengan standar (kondisi ideal). Sedangkan pada indikator yang mengalami kesenjangan menunjukkan bahwa terdapat perbedaan antara kondisi riil sudah sesuai dengan standar (kondisi ideal).

Kesenjangan tidak hanya ditinjau dari segi perencanaan pembelajaran saja, namun juga ditinjau dari segi pelaksanaan pembelajaran. Hasil analisis kesenjangan pada tiap indikator pelaksanaan pembelajaran dapat disajikan pada Tabel 3.
Berdasakan hasil analisis data di atas, diketahui bahwa indikator 1 (mengondisikan suasana belajar agar peserta didik siap mengikuti pembelajaran) tidak mengalami kesenjangan antara standar acuan dengan pelaksanaan pembelajaran yang dilaksanakan guru.

Terdapat 11 indikator pelaksanaan pembelajaran yang mengalami kesenjangan dengan kategori sangat kecil antara standar acuan dengan pelaksanaan pembelajaran yang dilaksanakan guru. Kesenjangan tersebut terdapat pada indikator 3 (menyampaikan kompetensi yang akan dicapai dan manfaatnya dalam kehidupan sehari-hari) dengan besar kesenjangan 13,4\%, indikator 4 (menyampaikan garis besar cakupan materi dan kegiatan yang akan dilakukan) dengan besar kesenjangan 10\%, indikator 6 (kegiatan inti pembelajaran dilakukan secara interaktif, inspiratif, menyenangkan, menantang, memotivasi peserta didik untuk berpartisipasi aktif) dengan besar kesenjangan 6,6\% , indikator 7 (kegiatan inti pembelajaran dapat memberikan ruang yang cukup bagi prakarsa, 
kreativitas, dan kemandirian sesuai dengan bakat, minat dan perkembangan fisik serta psikologis peserta didik) dengan besar kesenjangan $20 \%$, indikator 8 (peserta didik difasilitasi untuk melakukan proses mengamati, menanya, mengumpulkan informasi/mencoba, menalar/mengasosiasi, dan mengomunikasikan.) dengan besar kesenjangan $6,6 \%$, indikator 9 (pendidik senantiasa memperhatikan perkembangan sikap peserta didik pada kompetensi dasar dari KI-1 dan KI-2 (antara lain mensyukuri karunia tuhan, jujur, teliti, kerjasama, toleransi, disiplin, taat aturan, menghargai pendapat) dengan besar kesenjangan $16,6 \%$, indikator 10 (pendidik memberikan penilaian terhadap kompetensi dasardari KI-4) dengan besar kesenjangan 20\%, indikator 11 (peserta didik diarahkan untuk membuat rangkuman/simpulan pelajaran) dengan besar kesenjangan $20 \%$, indikator 13 (peserta didik diberikan umpan balik terhadap proses dan hasil pembelajaran) dengan besar kesenjangan $20 \%$, indikator 14 (pendidik melakukan penilaian terhadap hasil belajar siswa.) dengan besar kesenjangan 20\%, dan indikator 16 (Pendidik menyampaikan rencana pembelajaran pada pertemuan berikutnya) dengan besar kesenjangan 6,6\%.

Tabel 3. Analisis Kesenjangan pada Indikator Pelaksanaan Pembelajaran yang Disusun Oleh Guru Di SD Negeri 4 Kaliuntu

\begin{tabular}{|c|c|c|c|c|c|c|}
\hline \multicolumn{7}{|c|}{ Pelaksanaan Pembelajaran } \\
\hline $\begin{array}{l}\text { No. } \\
\text { Butir }\end{array}$ & Standar & Skor & $\begin{array}{l}\text { tanda } \\
\text { beda }\end{array}$ & Besar Beda & $\begin{array}{l}\text { persentase besar } \\
\text { beda }(\%)\end{array}$ & Kategori \\
\hline 1 & 100 & 100 & - & 0 & 0 & TK \\
\hline 2 & 100 & 66,67 & - & $-33,4$ & 33,4 & $\mathrm{~K}$ \\
\hline 3 & 100 & 86,87 & - & $-13,4$ & 13,4 & SK \\
\hline 4 & 100 & 90 & - & 10 & 10 & SK \\
\hline 5 & 100 & 46,67 & - & $-53,4$ & 53,4 & $\mathrm{CB}$ \\
\hline 6 & 100 & 93,4 & - & $-6,6$ & 6,6 & SK \\
\hline 7 & 100 & 80 & - & -20 & 20 & SK \\
\hline 8 & 100 & 93,4 & & $-6,6$ & 6,6 & SK \\
\hline 9 & 100 & 83,4 & - & $-16,6$ & 16,6 & SK \\
\hline 10 & 100 & 80 & - & -20 & 20 & SK \\
\hline 11 & 100 & 80 & - & -20 & 20 & SK \\
\hline 12 & 100 & 63,4 & - & $-36,6$ & 36,6 & $\mathrm{~K}$ \\
\hline 13 & 100 & 80 & - & -20 & 20 & SK \\
\hline 14 & 100 & 80 & - & -20 & 20 & SK \\
\hline 15 & 100 & 76,67 & - & $-23,4$ & 23,4 & K \\
\hline 16 & 100 & 93,4 & - & $-6,6$ & 6,6 & SK \\
\hline Jumlah & 1600 & 1293,40 & - & $-306,60$ & 306,60 & \\
\hline $\begin{array}{c}\text { Rata- } \\
\text { rata }\end{array}$ & 100 & 80,83 & - & $-19,17$ & 19,17 & SK \\
\hline
\end{tabular}

Tabel 3 tersebut menunjukkan, komponen pelaksanaan pembelajaran yang mengalami kesenjangan dengan kategori kecil (K) terletak pada nomor butir 2 yaitu pada indikator memberikan apersepsi terkait dengan kompetensi yang sudah dipelajari dan dikembangkan sebelumnya yang berkaitan dengan kompetensi yang akan dipelajari dan dikembangkan. Pada indikator ini, terdapat kesenjangan sebesar 33,4\%. Selanjutnya, komponen pelaksanaan pembelajaran yang mengalami kesenjangan dengan kategori kecil (K) juga terletak pada nomor butir 12 yaitu pada indikator peserta didik diarahkan untuk melakukan refleksi terhadap kegiatan yang sudah dilaksanakan dengan kesenjangan sebesar $36,6 \%$. komponen pelaksanaan 
pembelajaran yang mengalami kesenjangan dengan kategori kecil (K) yang terakhir adalah nomor butir 15 yaitu pada indikator pendidik merencanakan kegiatan tindak lanjut dalam bentuk pembelajaran remedi, program pengayaan, layanan konseling dan/atau memberikan tugas baik tugas individual maupun kelompok sesuai dengan hasil belajar peserta didik dengan kesenjangan sebesar $23,4 \%$.

Kemudian, dari sajian data pada tabel 3, diketahui bahwa komponen pelaksanaan pembelajaran yang memiliki tingkat kesenjangan yang paling besar adalah nomor butir 5 yaitu pada indikator menyampaikan lingkup dan teknik penilaian yang akan digunakan. Pada indikator ini terjadi kesenjangan sebesar 53.4\%. Hasil analisis tersebut menunjukkan bahwa komponen pelaksanaan pembelajaran nomor butir 5 mengalami kesenjangan dengan kategori cukup besar (CB).

\section{Pembahasan}

Berdasarkan hasil studi dokumentasi serta analisis data diketahui bahwa rata-rata perolehan skor RPP yang disusun guru SD N 4 Kaliuntu adalah sebesar 87,83 . Hal tersebut berarti terjadi kesenjangan sebesar $12,17 \%$ dan tergolong kategori sangat kecil (SK). Berdasarkan hasil analisis data tersebut, berarti terdapat beberapa komponen atau indikator dalam RPP yang disusun pendidik belum sesuai dengan Permendikbud No.103 Tahun 2014.

Kesenjangan tersebut, yang pertama terletak pada subkomponen alokasi waktu. Pada RPP yang disusun oleh guru kelas III dan guru kelas VI, alokasi waktu yang dicantumkan tidak sesuai antara alokasi waktu yang terdapat dalam identitas RPP

dengan alokasi waktu pada komponen kegiatan pembelajaran.

Kesenjangan juga terjadi pada subkomponen Kompetensi Dasar. Dalam Permendikbud Nomor 103 Tahun 2014 dalam penyusunan RPP, kompetensi dasar harus memuat secara utuh kompetensi dasar sikap spriritual (KD dari KI-1), sosial (KD dari KI2), pengetahuan (KD dari KI-3), dan keterampilan (KD dari KI-4). Namun dalam kenyataan di lapangan, guru kelas VI di SD N 4 Kaliuntu hanya memuat kompetensi dasar KI-3 dan KI-4 saja. Kesenjangan juga terletak pada subkomponen indikator pencapaian kompetensi dengan indikator mencantumkan indikator pencapaian kompetensi dan dirumuskan berdasarkan kompetensi dasar. Guru kelas 1, kelas 3, dan guru kelas 4 hanya memuat indikator dari KD dari KI-3 dan KD dari KI-4. Pada bagian subkomponen materi dalam RPP juga ditemukan kesenjangan. Permendikbud Nomor 103 Tahun 2014 menghendaki dalam RPP kurikulum 2013 harus memuat fakta, konsep, prinsip, dan prosedur yang relevan. Dalam RPP yang disusun oleh guru-guru kelas di SD Negeri 4 Kaliuntu, materi yang dicantumkan dalam RPP kurang lengkap. Kemudian, kesenjangan juga terjadi pada subkomponen kegiatan pembelajaran. Pada RPP yang disusun oleh guru kelas III masih menggunakan model pembelajaran yang kurang inovatif. Kesenjangan juga terjadi pada indikator memfasilitasi peserta didik untuk belajar secara mandiri karena pembelajaran lebih banyak diarahkan pada pembelajaran berdiskusi atau kelompok, kemandirian belajar diarahkan pada kegiatan menjawab pertanyaan yang ada dalam buku siswa.

Kesenjangan dalam subkomponen kegiatan pembelajaran juga terdapat dalam pada indikator menjadikan lingkungan sekitar (kelas maupun halaman sekolah) sebagai sumber belajar, beberapa RPP yang disusun masih belum menjadikan lingkungan sekitar sebagai sumber belajar. Dalam RPP yang disusun guru hanya beberapa objek yang dimanfaatkan. Kesenjangan terjadi pula pada indikator memuat rancangan program pemberian umpan balik positif dan penguatan. Pada RPP yang disusun pendidik khususnya kelas IV belum memuat rancangan program pemberian umpan balik sesuai dengan tuntutan Permendikbud No.103 Tahun 2014. Kesenjangan selanjutnya terjadi pada subkomponen penilaian hasil belajar. Pada subkomponen ini, ditemukan kesenjangan pada RPP yang disusun oleh guru khususnya kelas III, kelas IV dan kelas VI. Pada subkomponen penilaian hasil belajar guru kelas III, kelas IV dan kelas VI hanya mencantumkan teknik penilaian dan instrument penilaian.

Kesenjangan juga terjadi pada subkomponen media dan sumber belajar pada 
RPP susun oleh pendidik SD N 4 Kaliuntu. Kesenjangan tersebut terletak pada indikator penerapan teknologi informasi dan komunikasi. RPP yang disusun oleh pendidik seluruh kelas yang menjadi subjek penelitian tidak mencantumkan/memanfaatkan teknologi informasi dan komunikasi. Selain itu, kesenjangan juga terjadi pada indikator mencantumkan sumber belajar yang dapat berupa buku, media cetak dan elektronik, alam sekitar dan sumber belajar lain yang relevan. Pada RPP yang disusun oleh pendidik khususnya kelas II, kelas III dan kelas VI. sumber belajar yang dicantumkan belum bervariasi. Sumber belajar bagi peserta didik hanya sebatas buku dari pemerintah.

Wujud hasil evaluasi program adalah sebuah rekomendasi dari evaluator untuk pengambilan keputusan (Arikunto, 2008). Kesenjangan objek perencanaan pembelajaran oleh pendidik SD Negeri 4 Kaliuntu sebesar $12,17 \%$ termasuk kategori sangat kecil. Oleh karena itu, perencanaan pembelajaran yang telah disusun oleh SD Negeri 4 Kaliuntu layak untuk diteruskan dalam pembelajaran dengan adanya perbaikan pada beberapa komponen yang belum sesuai dengan standar acuan (Permendikbud No.103 Tahun 2014).

Berdasarkan hasil observasi terhadap pelaksanaan pembelajaran yang dilaksanakan oleh pendidik di SD Negeri 4 Kaliuntu kemudian dianalisis, diperoleh bahwa terjadi kesenjangan sebesar $19,17 \%$ dan tergolong kategori sangat kecil (SK) pada komponen pelaksanaan pembelajaran yang dilaksanakan pendidik SD Negeri 4 Kaliuntu. Berdasarkan hasil analisis data tersebut, berarti terdapat beberapa komponen atau indikator dalam pelaksanaan pembelajaran yang dilaksanakan pendidik belum sesuai dengan permendikbud Nomor 103 Tahun 2014.

Kesenjangan pertama terjadi pada kegiatan pendahuluan yaitu pada indikator pemberian apersepsi. Hampir semua guru di SD Negeri 4 Kaliuntu belum sepenuhnya menyampaikan apersepsi yang mengaitkan antara kompetensi yang telah dipelajari sebelumnya dengan kompetensi yang akan dipelajari.

Kemudian kesenjangan pada subkomponen kegiatan pendahuluan juga terdapat pada indikator menyampaikan kompetensi yang akan dicapai dan manfatnya dalam kehidupan sehari-hari. Berdasarkan hasil observasi yang dilakukan, ditemukan bahwa guru kelas I, II, III dan IV belum menyampaikan kompetensi yang akan dicapai dan manfatnya dalam kehidupan sehari-hari secara jelas. Kesenjangan juga terdapat pada indikator menyampaikan garis besar cakupan materi dan kegiatan yang dilakukan. Kesenjangan pada indikator ini ditemukan pada guru kelas I, II dan IV. Pada indikator ini beberapa guru belum sepenuhnya atau kurang lengkap dalam menyampaikan garis besar cakupan materi.

Kesenjangan tertinggi pada subkomponen kegiatan pendahuluan terdapat pada indikator menyampaikan lingkup dan teknik penilaian yang akan digunakan. Hampir semua pendidik tidak menyampaikan teknik penilaian yang akan digunakan. Hal tersebut tidak sesuai dengan Permendikbud No.103 Tahun 2014 yang menuntut penyampaian teknik penilaian yang akan digunakan pada kegiatan pendahuluan.

Berdasarkan observasi yang telah dilakukan, pada subkomponen kegiatan inti juga ditemukan beberapa kesenjangan. Kesenjangan tersebut terdapat pada beberapa indikator. Kesenjangan yang pertama adalah pada indikator pembelajaran dilakukan secara interaktif, inspiratif, menyenangkan, menantang, memotivasi peserta didik untuk berpartisipasi aktif. Berdasarkan hasil observasi, guru kelas III dan VI belum dapat membuat peserta didik untuk aktif dalam proses pembelajaran terlihat hanya beberapa siswa yang aktif.

Kesenjangan dalam subkomponen kegiatan inti juga terdapat pada indikator kegiatan inti pembelajaran dapat memberikan ruang yang cukup bagi prakarsa, kreativitas, dan kemandirian sesuai dengan bakat, minat, dan perkembangan fisik serta psikologis peserta didik. Pada indikator ini guru-guru sudah mendekati sesuai dengan amanat Permendikbud Nomor 103 Tahun 2014, hanya saja belum sepenuhnya dilakukan.

pendapat).

Kemudian kesenjangan juga terdapat pada indikator melakukan penilaian terhadap KD dari KI-4 yakni penilaian keterampilan. Guru sudah hampir semua melaksanakan penilaian keterampilan peserta didik namun belum dilakukan secara maksimal. Jika melihat hasil analisis data bahwa kegiatan inti yang dilaksanakan guru di SD Negeri 4 
Kaliuntu sudah mendekati kesesuaian dengan Permendikbud Nomor 103 Tahun 2014, hanya beberapa indikator masih terdapat kesenjangan.

Selanjutnya, pada subkomponen kegiatan penutup juga ditemukan kesenjangan. Kesenjangan pertama terdapat pada indikator peserta didik diarahkan untuk membuat rangkuman/kesimpulan pelajaran. Pada indikator ini guru memang sudah melaksanakannya, namun karena alasan keterbatasan waktu, ada beberapa guru belum sepenuhnya mengajak siswa membuat simpulan secara lengkap, yaitu guru kelas I, II dan III. Kemudian kesenjangan juga terjadi pada indikator peserta didik diarahkan untuk melakukan refleksi terhadap kegiatan yang sudah dilaksnakan. Hasil observasi menunjukkan hampir semua guru belum mengarahkan peserta didik untuk melakukan refleksi terhadap kegiatan yang sudah dilaksanakan.

Kesenjangan pada subkomponen kegiatan penutup juga terdapat pada indikator peserta didik diberikan umpan balik terhadap proses dan hasil belajar. Dalam indikator ini kesenjangan terletak pada semua guru, hal ini dikarenakan guru kurang sesuai dalam memberikan umpan balik terhadap proses pembelajaran dan hasil belajar peserta didik. Kegiatan yang dilakukan oleh guru belum sepenuhnya sesuai dengan amanat dari Permendikbud Nomor 103 Tahun 2014.

Selain itu, kesenjangan juga terjadi dalam subkomponen pemberian tindak lanjut dari pendidik kepada peserta didik dalam bentuk remidi, pengayaan, dan atau pemberian tugas. Pemberian tindak lanjut dalam bentuk remidi, pengayaan, dan atau pemberian tugas dimaksudkan agar peserta dapat memperbaiki hasil belajar yang belum memenuhi standar. Akan tetapi, kesenjangan ini ditemukan pada semua pendidik hal ini dikarenakan tidak semua pendidik melaksanakannya secara lengkap. Pada indikator guru menyampaikan rencana pembelajaran pada pertemuan berikutnya juga ditemukan kesenjangan. Kesenjangan tersebut ditemukan pada guru kelas III dan IV yang hanya menyampaikan halaman materi yang akan di pelajari selanjutnya.

$$
\text { Madaus (dalam Putro, 2011) }
$$

menyatakan bahwa discrepancy model merupakan model evaluasi yang berangkat dari asumsi bahwa untuk mengetahui kelayakan suatu program, evaluator dapat membandingkan antara apa yang seharusnya dan apa yang diharapkan terjadi (standard) dengan apa yang sebenarnya terjadi (performance) sehingga dapat diketahui ada tidaknya kesenjangan (discrepancy) antara keduanya yaitu standar yang ditetapkan dengan kinerja sesungguhnya. Wujud dari hasil evaluasi program adalah sebuah rekomendasi dari evaluator untuk pengambilan keputusan (Arikunto, 2008). Kesenjangan objek pelaksanaan pembelajaran oleh pendidik SD Negeri 4 Kaliuntu sebesar 19,17\% termasuk kategori sangat kecil. Oleh karena itu, pelaksanaan pembelajaran yang telah dilaksanakan oleh pendidik SD $\mathrm{N}$ egeri 4 Kaliuntu layak untuk diteruskan dalam pembelajaran dengan adanya perbaikan pada beberapa komponen yang belum sesuai dengan standar acuan (Permendikbud No.103 Tahun 2014).

\section{SIMPULAN}

Berdasarkan hasil analisis data dapat disimpulkan hal-hal sebagai berikut. I) Besamya kesenjangan antara implementasi kurikulum 2013 di SD Negeri 4 Kaliuntu dan Permendikbud Nomor 103 Tahun 2014 ditinjau dari perencanaan pembelajaran adalah $12,17 \%$ dan tergolong kategori sangat kecil (SK). Kesenjangan tersebut terletak pada indikator kegiatan pembelajaran, penilaian hasil belajar, media dan sumber belajar. 2) Besamya kesenjangan antara implementasi kurikulum 2013 di di SD Negeri 4 Kaliuntu dan Permendikbud Nomor 103 Tahun 2014 ditmjau dari pelaksanaan pembelajaran adalah $19,17 \%$ dan tergolong kategori sangat kecil (SK). Kesenjangan tersebut terdapat pada indikator pemberian apersepsi, penyampaian teknik penilaian yang akan digunakan guru, peserta didik diarahkan refleksi terhadap kegiatan yang sudah dilaksanakan, dan pemberian tindak lanjut dalam bentuk remidi, pengayaan, dan atau pemberian tugas.

Untuk mengatasi kesenjangan perencanaan pembelajaran Kurikulum 2013 dan meningkatkan kesesuaian pelaksanaan Permendikbud Nomor 103 Tahun 2014 dalam pembelajaran oleh pendidik, maka kepada beberapa pihak terkait harus saling bekerja sama dan mengambil kebijakan-kebijakan 
serta merancang suatu program yang dapat meningkatkan pemahaman pendidik terhadap pembelajaran yang diamanatkan dalam Permendikbud Nomor 103 Tahun 2014. Beberapa hal yang disarankan adalah sebagai berikut. (1) Guru hendaknya selalu bersikap adaptif terhadap perubahan-perubahan yang terjadi dalam kurikulum dan peraturanperaturan atau acuan dan meningkatkan kemampuannya dalam mengimplementasikan kurikulum 2013 dengan mengikuti berbagai kegiatan seperti pelatiahan KKG, dan kegiatan lainnya. (2) Kepala sekolah hendaknya mengevaluasi kinerja guru dalam menyusun RPP dan pelaksanaan pembelajaran, agar ketika ada hal yang kurang sesuai dengan standar bisa di koreksi. Kepala sekolah agar selalu menginstruksikan kepada guru-guru agar mengikuti berbagai kegiatan pelatihan, mengenai penyusunan RPP dan pelaksanaan pembelajaran Kurikulum 2013 sesuai Permendikbud No.103 Tahun 2014 .(3) Pemerintah hendaknya hendaknya lebih mengintensifkan sosialisasi terkait pembelajaran yang sesuai standar kepada guru melalui berbagai kegiatan pelatihan, workshop, seminar, lokakarya, serta kegiatan lain kepada guru yang difokuskan pada tata cara penyusunan RPP Kurikulum 2013 dan pelaksanaan pembelajaran mulai dari cara melakukan kegiatan pendahuluan, inti dan penutup yang sesuai Permendikbud No.103 Tahun 2014. (4) Peneliti lain hendaknya melakukan penelitian mengenai evaluasi terhadap implementasi pembelajaran Kurikulum 2013 dan lebih luas cakupan satuan pendidikannya untuk mengetahui apakah masih terdapat kesenjangan-

kesenjangan dalam implementasi pembelajaran Kurikulum 2013 sehingga dapat dicarikan solusi dan diharapkan dapat meningkatkan kualitas pendidikan demi kemajuan bangsa.

\section{DAFTAR RUJUKAN}

Arikunto, Suharsini dan Cepi Safrudin Abdul Jabar.2008. Evaluasi Program Pendidikan. Jakarta: Bumi Aksara

Hadi, Samsul dan Mutrofin. 2005. Pengantar metode Riset

Pengantar metode Riset

Evaluasi.Yogyakarta: PT. Kurnia Kalam Semesta.

Kamil, Ahmad. 2014. Pentingnya Kurikulum dalam Pendidikan. Tersedia pada http://www.

kompasiana.com/achmadkamil/pen tingnya-kurikulum-terhadap prosespendidikan (diakses pada 15 Desember 2015)

Kurniasih, Imas dan Berlin Sani. 2014. Sukses Mengimplementasikan Kurikulum 2013. Jakarta: Kata Pena

Pertiwi, Putu Arik Indah. 2015. "Analisis diskrepansi pembelajaran kurikulum 2013 berdasarkan permendikbud nomor 65 tahun 2013 di SD Negeri 3 Banjar jawa". Undiksha, Volume 3, Nomor 1. Tersedia pada http://ejournal.undiksha.ac.id/index .php/JJPGSD/article/viewFile/5154 /3896(diakses pada tanggal 10 Nopember 2015).

Putro, Eko Widoyoko. 2011. Evaluasi Program Pembelajaran. Yogyakarta: Pustaka Pelajar

Suciptawati, Ni Luh Putu. 2009. Metode Statistika Nonparametrik. Denpasar: Udayana University Press

Sudarma, I Made. 2011. Analisis Deskrepansi Pelaksanaan Standar Proses Kelompok Mata Pelajaran IPTEK Pada SMA Rintisan Bertaraf Internasional di Kabupaten Klungkung Tahun 2010/2011. Tesis (tidak diterbitkan) Program Pasca Sarjana, Universitas Pendidikan Ganesha 